\title{
Impact of Broken Homes on Education of Children: A Sociological Perspective
}

\author{
Ilori Oladapo Mayowa*
}

Department of Sociology, Faculty of the Social Sciences, Ekiti State University, Ado Ekiti, Ekiti Sate, Nigeria

\begin{abstract}
Broken Homes, until very recently is very alien to the African family structure/setting. But it is discovered that the trend of Broken Homes is growing in the world all over and Africa is not left behind in this trend. One can deduce the growing trend of Broken Homes in Africa to the incursion of modernization and industrialization into the African family setup. The traditional African family is much knitted together with a lot of love bound. But with modernization and civilisation are fast becoming the order of the day in all sectors of daily life, family is not left behinln Nigeria for instance, the existence of Broken Homes is unknown, and when they existed, they are ignored as exceptional cases. In Africa, no one is happy to be identified as being raised in a Broken Home. In order words, the pride of an average African Child is to be brought up in a family where the man and his dear wife are living together, loving each other and each one of them performing his/her social responsibility and obligation towards the raising of the children and the survival of the family at large. This research looked at how broken home has affected education of children in society today and proffered solutions on how the scourge could be contained in our society. The research is mainly literature and conceptual. Literature in this study was sourced mainly from secondary data like journals, books, and the views of other scholars in this field.
\end{abstract}

Keywords: Education, Academic Success, Broken Homes, Family, Modernization.

\section{INTRODUCTION}

Broken Homes have been seen as un-African and where it happened, it has been treated as a taboo, unideal, and an exceptional case. However, the rate of broken homes in marriages is on the rise and becoming alarming in society today. The various homes and families are expected to serve as and be filled with joy, happiness with a lot of guaranteed security and comfort but it is rather unfortunate and pitiful that the home is neglecting its primary functions thereby causing a lot of damages to the education of the children from such homes. A family which is supposed to be the foundation and the smallest unit based on the blood relationship of the society will be found wanting in this duty when it is broken. Family is required to support, protect and educate traditional norms, values their children when young, who also, in turn, love, respect, revere and obey their parents and maintain them when they grow old. The emergence of Broken Homes in society in recent times is threatening the basic roles and responsibilities of the family. In Nigeria, the existence of Broken Homes is unknown and when they existed, they are ignored as exceptional cases. Currently, Broken Homes are fast-growing family patterns both inside and outside Nigeria and have become even more common than the so-called nuclear family, consisting of the father, mother, and the children (Tenibiaje M.O et al., 2011). Factors such as

*Address correspondence to this author at the Department of Sociology, Faculty of the Social Sciences, Ekiti State University, Ado Ekiti, Ekiti Sate, Nigeria; E-mail: mayowadapo77@gmail.com, oladapo.ilori@eksu.edu.ng divorce, separation, death of a parent, unwanted pregnancy or both to unmarried couples, and singleparent adoption are the major causes of Broken Homes in our society today (Amato, 2000).

A broken home is regarded as a household in which only one parent lives with a child or children (Pollitt, 1994). A broken home is a situation in which either the man or the woman in a marriage is responsible for the financial, material, and emotional needs of the family. It is taking care of family responsibilities (which include caring for the children) without the father's or mother's contribution (Achakpa, 1999). It means the other parent is absent as opposed to a co-parent, meaning that the parent is not the only parent regardless of whether or not they are a couple. A broken home is a situation in which someone brings up a child on his/her own because the other parent is not living with them. A Broken Home is a parent not living with a spouse or partner, who has most of the day-to-day responsibilities in raising the child or children (Dowd Nancy, 1997).

The overall effect of Broken Homes on a child's education cannot be underestimated. There is no doubt that Broken Home can either make or mar a child's academic performance. The first point of call-in child's education is the family. Family is expected to lay a good foundation education, both formal and informal for the child. The family lays the psychological, moral, and spiritual foundation in the overall development of the child (Agulana, 2000). The environment in which a child finds himself/herself goes a long way to determine his/her ability and ultimately his academic performance 
(Ayodele, 2007). The structure of a family has a long way in determining the academic success or otherwise of a child. The family and its structure play a great role in a child's academic performance (Rochlkepartain, 2003). Children from relatively stable homes where the wife and the husband leave together thrive best because the two parents under the same roof can give the children deal of care and attention, encouraging them, on one hand, to develop their own life and interests and providing them on the other hand with a secure base which they can return and in which they can always find comfort and support. Children from Broken Homes are more likely to drop out of school because of support from both parents. Every child deserves and needs the love of both parents to be able to perform excellently well in school. Children of divorced parents are roughly two times more likely to drop out of school than their peers who benefit from living with parents who are not divorced (Mclanahan, 1994). Also, children from Broken Homes may not have the wherewithal to make ends meet financially and may subsequently force such child/children to indulge in stealing to fend for themselves. Broken Homes are often financially vulnerable as compared to two-parent families. This unfortunate economic circumstance can draw these families to disorganised neighbourhoods where crime and delinquency are rampant (Alfrey, 2010). Broken Homes may necessitate a child not completing his/her education. This may be due to a lack of finance on the part of either the single mother or the single father.

\section{OBJECTIVES OF THE STUDY}

The main objective of this research is to know the root causes of broken homes, their effects on a child's education, and to recommend how the menace can be checked.

\section{LITERATURE REVIEW}

\subsection{Causes of Broken Homes}

\subsubsection{Divorce}

Divorce has been identified as one of the factors responsible for Broken Homes in our society today, in fact, divorce has been identified as the major cause of Broken Homes today. Divorce can be said to a situation where a marriage or marital union is terminated. Divorce is the complete break-up or dissolution of marriage through legal means (Mirror, 2003). It is also a situation that involves cancelling or re-organization of the legal duties and responsibilities of marriage, thus dissolving the bonds of matrimony between a married couple under the rule of law of the particular country. Some of the remote causes of divorce are:
(a) Infidelity
(b) Financial Incapability
(c) Incompatibility
(d) Misconduct
(e) Health Challenges

Divorce has been both the husband and the wife to abandon their marital vows and go separate ways. Divorce has inflicted a major injury on the upbringing of the children in such family especially the education. Both formal and informal education has been the primary function of the family and what happens to us from the day we were born till the day we leave this world. Education is a weapon for combating ignorance, poverty, and disease, it is a bridge between confusion and comprehension, it is a dam for conserving man's store of civilization, it is a means for transporting from a state of intellectual subservience to a state of intellectual sovereignty (Nwachi,2000). Divorce effects are economically, mentally, emotionally, physically and it exhibits depression and anxiety (Kurdeck, 1991; Amato, 1994). Divorce may likely bring economic stress on the single father or the single mother, especially in a situation where the income of either of them is low and cannot cater to the needs of the family. Children from divorced families have elevated risks of problems such as physical disorder, (Aghajanian et.al, 1996). In another development, children from divorced families are likely to have lower academic achievement than the children from the families where the couple is living together.

\subsubsection{Death}

Of course, death is one of the causes of Broken Homes in our society. This is the necessary end of man on earth. This is when everything about man ceases to exist. Death can also refer to the termination of life when everything about man ceases to function (Psalms 104 vs 29). The death of a partner in marriage at any age is one of the most challenging events in the marriage. The major causes of death in the developing world include accidents, illness, childbirth, and recently, the scourge of HIVIAIDS. Hunter \& Williamson (2000) believed that one in ten African children under the age of 15 years has lost one or both parents. How the other 
partner in the marriage takes the grieve depends on the length of the relationship, whether the death is sudden or expected, the support such partner enjoys from each other, the financial situation of another partner, and most importantly, whether, over time, the other partner can make a life out of what that has happened. There is no doubt that the death of a partner in a marriage will affect the running of such a home, especially if such a dead partner is the breadwinner of the family and this will have a multiplier effect on the education of the children in such homes. This can be a devastated and most traumatic event in a child's life especially in the developing world where no arrangement and/or provision is made by the government to take care of children from such families. Parents are expected to be role models to the children and also expose the children to education (formal \& informal) in life. Children whose exposure to parental role modelling is limited due to parental death may lack those skills and as a consequence may be less successful in school and have other issues (Steele, Sigle-Rushton \& Kravdal, 2009).

\subsubsection{Unexpected Pregnancy}

Unexpected pregnancy can also lead to Broken Homes. This is a situation in which a woman conceived when it is not expected, not intended and mistimed. It is more common among the youth to engage in premarital sex and this can lead to unwanted pregnancy if necessary precautionary measures (contraceptives) are not put in place. Every year, almost one million girls become pregnant in Nigeria and many of these pregnancies are unintended and unplanned (Amobi \& lgwegbe, 2001). Most of the time, unwanted pregnancies started as unplanned pregnancies but occasionally the planned pregnancy may end up being unwanted pregnancies (Baginsk, 2007). Unwanted pregnancy has become an important issue in society because of its negative association with the social and health outcomes for both mothers and children. Unwanted pregnancy has had a major negative on the well-being of the affected family especially the woman. Unwanted pregnancy can be a major source of dispute in homes, especially where there had been a previous agreement between a man and woman on the number of children the family will have during courtship. The economic situation in the country can equally make any unwanted pregnancy in the family confrontational between the husband and wife. Some researches had even shown negative effects of unwanted pregnancy on the health of the children which invariably affect the education of such children.

\subsection{Effects of Broken Homes on Family and Society}

\subsubsection{Delinquency}

Researches correlated with the structure of the family and delinquent activities in the children. It was observed that children from a Broken Home are likely to be delinquent than children from a family where the husband and the wife are living together. Family is the foundation of human society; children who are rejected by their parents, who grow up in homes with considerable conflict, or who are inadequately supervised are at the greatest risk of becoming delinquent (Wright \& Wright, 1994). Children from Broken Homes will have less level of family supervision and control than the children from families where the husband and the wife are living together. When one parent is living in the house as opposed to two, it is more difficult to supervise children all the time (Dogget, 2004). The level of affection and emotionally bond in the Broken Homes is always less than that of the full family and this will harm the attitude and behaviour of such a child. In this case, there are tendencies for children who did not have the necessary and required family bound to be vulnerable to training from the peer group and this can lead to delinquency. Lack of parental control contributes not only directly to children's anti-social behaviour, but also indirectly as it contributes to exposing them to associate with deviant peers, which is predictive of higher levels of deviant acts (Okorodudu, 2010). It has been revealed that children from a Broken Homes or stepfamily may have lower levels of control placed on them than children from biological households (Hagan, 1990). Empirical evidence has shown that children from intact homes will be well taken care of a better socialised, this is because the process of socialisation depends on both parents playing complementary roles in raising such children (Azuka-Obieke, 2013). Also, children from Broken Homes may not have the wherewithal to make ends meet financially and may subsequently force such child/children to indulge in stealing to fend for themselves. Broken Homes are often financially vulnerable as compared to two-parent families. This unfortunate economic circumstance can draw these families to disorganised neighbourhoods where crime and delinquency are rampant (Alfrey, 2010).

\subsubsection{Poor Education Performance}

This is another side effect of Broken Homes in our society today. There is no doubt that the education of a child will suffer and experience retardation in a Broken 
Homes family structure; this is because parent plays a very vital role in the academic development of the children. When living in a divorced single-parent household, children tend to disengage from school at an early age (Astone \& McLanahan, 1991). A child's academic performance improves when both parents are actively involved in the education of such a child (Fadeye, 1985, Nyarko, 2007, Nyarko \& Vorgelet, 2007). The overall effect of family structure on a child's academic performance cannot be underestimated. The success of a child in the school depends on both parents playing their various parts in the upbringing of such child, two good heads are better than one. Fadeiye (1985) found that in two parents' homes, both parents have roles to play in child education. The father is to give the necessary tools for educational advancement, while the mother is to supplement the father's efforts in return. Children who grow up in a Single Parenthood household are more likely to demonstrate emotional and behavioural problems to live in poverty and do poorly in school compared to children who live with both biological parents (Remez, 1992).

\section{THEORETICAL FRAMEWORK}

\subsection{Environmental Determinism}

Environmental Determinism will be adopted as the theoretical concepts in this paper.

Environmental Determinism is a theory or doctrine based on the occurrences in nature, social or psychological phenomena causally determined by preceding events in natural laws (Doyle, 2011). Environmental Determinism posited that the environment where an organism develops has a great influence on such an organism. From a metaphysical and philosophical point of view, for everything that happens there are conditions such that without these conditions, nothing else could happen. Researches have shown that the influence of the environment where man develops cannot be underestimated in determining the action of man. It is believed that environmental determinism is the doctrine that human growth, human development, and activities are controlled by the physical environment, hence, factors of culture, race, and intelligence are supposed to derive from the malign influence of climate and other aspects of human habitat. The physical environment (family) which a child develops has a great impact on the psychology of such a child and will have a multiplier effect on the education of such a child. A chaotic environment can contribute to the psychological and physiological stress that can negatively affect children's social interactions as well as the ability to effectively participate in school activities.). The structure of a family (which is regarded as an environment) has a long way in determining the academic success or otherwise of a child. The family and its structure play a great role in a child's academic performance (Rochlkepartain, 2003). Children from relatively stable homes where the wife and the husband leave together thrive best because the two parents under the same roof can give the children deal of care and attention, encouraging them, on one hand, to develop their own life and interests and providing them on the other hand with a secure base which they can return and in which they can always find comfort and lack of support. Children from Broken Homes are more likely to drop out of school because of support from both parents. Researches have shown that a child's educational performance and intellectual development are related. Studies have shown that children who do well in school academic activities come from families that provide a supportive and enriched environment for learning at home. And one of the ways a family can be a good environment for the child to learn is stability at home. A stable home will no doubt provide a veritable environment for a child to succeed academically.

\section{CONCLUSION}

The traditional African family is the one that is very knitted and with a very strong bond existing among the members. But with the advent of modernisation and civilisation, the traditional Africa family began to weaken and the existing bond began to give way. Consequently, the family began to experience broken relationships and collapse in marriages. No doubt, the increase in broken marriage will have a consequential effect on the educational well-being of the children in such a home. Most children are backward in school today, not because they are not brilliant, but it is informed by the family background they come from. And children who performed poorly in education cannot make a happy and progressive society. Educationally backward children cannot make a better society. A stable marriage will be an ingredient for a solid child's education and progressive society.

\section{RECOMMENDATIONS}

\subsection{Economy}

The economy of a society plays a prominent role in the sustainability of the family structure. There is no 
doubt that the economy plays an important role in the rate of divorce in society. In order words, the economy of a country will no doubt a great impact on the rate of Broken Homes in such country. The economic recession has led to a high rate of unemployment and a high rate of job losses in the affected country. Unemployment is a major and determining effect in the life of a man or woman. The effect of recession is a decrease in family income such that families cannot even afford to take care of the family needs including payment of the school fees. It affects not only the concerned individual but his/her family will also be a partaker in the situation likewise the society at large. The impacts of unemployment in the family include poverty, hardship, strained relationships, and poor health. Unemployment is very dangerous to the overall standard of living of a family. This is because working and securing jobs is one of the determinants of the standard of living because people especially in this part of the world derive their income from their work. Unemployment has increased the level of frustration in the family and has led to unhappiness in the family in some cases. Unemployment has reduced the bond and affection between the husband and the wife, and the children in some cases. Family cohesion becomes more challenging as conflict among members of family may escalate during unemployment. Researches have shown elevated rates of violence in families experiencing hard times as a result of unemployment and economic recession. There is some evidence that both children maltreated and domestic violence are increasing in the face of unemployment in the family. And this will harm the education of the children in the affected family. Many studies on family instability have focused on changes in women's earnings, perhaps because the rise in married women's employment coincided historically with a rise in marital dissolution (Lewin, 2005).

Consequently, the better an economy, the more stable a family. Government should run policies that will improve the economy, to have an improved standard of living and as well improve the per capita income of families which will enhance family growth and stability. Economic stability and growth will reduce the rate of family violence and the level of poverty in the families. Good economy policies will enable the family to have jobs and this will eventually bring more income to the family, hence there will be family cohesion and it will reduce the rate of divorce and single parentage. It is believed that two-parent families will improve the welfare and general being of the family, this will keep the family intact and eliminate union dissolution.

\subsection{Government Welfare Package for Children from Broken Homes}

An improved government welfare package such as free education and scholarship for children from broken homes and single parentage can also improve the academic performance of children from the Broken Homes. The scholarship helps to alleviate the sufferings of the single parent in the Broken Homes and it eradicates the challenges of higher education sponsorship in the Broken Homes. A scholarship scheme/package for the single parent will help such single parent not only with their tuition but, if necessary, with living expenses, daycare, and other needs as they pursue higher education. The scholarship will help to increase the enrolment of the children in schools and at the same time, in the payment of their school fees as well as examinations fee. It will also help to procure school items and study materials which may be difficult to get if the Broken Homes and have a positive impact on their psychology. Scholarships have been good and helpful to poor pupils and students because the more pupil and students get a scholarship, the better it is (Bartley, 2010).

\subsection{Schools/Colleges should have Counsellors}

Both Government and various schools/colleges should make provision for the services of guidance and counselling units in the various schools. This Unit plays an important role in the development of children and contributes a lot to the future success of the children. This Unit is capable of transforming and helping children who are downcast to find the correct rhythm for success. The Guidance and Counselling Unit can shape the orientation in a child from the negative idea that is planted in the child as a result of the family structure. It is in this vein that the guidance and counselling unit will be needed to help such children from the Broken Homes to mould their future through therapy. The Counsellors by their training are expected to be friends with the school child, listen to the child's complaints, shortcomings and proffer guidance to the child in a quest of moulding the child in the right path to take in their life pursuit (Ebizie, Enajedu \& Nkechi, 2016).

\subsection{Birth Control Methods}

Birth Control methods, in general, are directly linked to a wide array of benefits to the family stability and 
peace in the society. Birth Control methods will provide more educational and economic opportunities for young women, improved maternal and infant health greater family wellbeing, and reduce public spending. Birth Control can check and reduces the rate of divorce in society. For instance, they have been divorced situations which are caused by unplanned pregnancies. Unintended births can lead to a higher level of chaos and turmoil between the parents and within the family. Such relationship turmoil creates troubling environments for a child's education. Parents who have a birth resulting from an unplanned pregnancy are less likely to be in a committed relationship, less likely to move into a more formal union, and more likely to have high levels of relationship conflict and unhappiness. Researches have shown that children born unintended are at a greater risk of child abuse and neglect, poor mother-child attachment, cognitive and physical deficits, and so on. Mohase (2006) asserted that teenage pregnancy has a lot of social consequences which include school dropout or interrupted schooling, falling prey to criminal activity, abortion, ostracism, child neglect, school adjustment difficulties for their children, adoption, lack of social security, poverty, repeated pregnancy and negative effects on domestic life. On this note, there should be an agreement between the husband and wife on the number of children the family is intended to have. Birth Control methods should be adopted to guide against unintended birth. Birth Control will go a long way to stabilise the family and reduce the rate of divorce resulting from unintended pregnancy.

\section{REFERENCES}

Achakpa. Priscilla. (1999). Women and Crime: A Sociological Perspective. National Concorde:26.

Aghajanian. Akbar. (1996). Some Notes on Divorce in Iran. Journal of Marriage and the Family: 48(4):749-755. https://doi.org/10.2307/352567

Agulana G.G (2000). Family Structure and Prevalence of Behavioural Problems among Nigerian Adolescents. The Counsellor:154161.

Amato. P.R (2000). Parental Divorce and the Well-Being of Children. A Metal Analysis, Psychological Bulletin:110:26-46. https://doi.org/10.1037/0033-2909.110.1.26

Amato P.R (1994). The Impact of Divorce on Men and Women in India and US, Journal of Comparative Family Studies:25:207-221. https://doi.org/10.3138/jcfs.25.2.207

Amobi. L.Ilika \& Igwegbe. Anthony (2001). Unitended Pregnancy among Unmarried Adolescence and Young Women in Anambra State, South East, Nigeria.

Alfrey. Curt. (2010). Juvenile Delinquency and Family Structure: Implication for Marriage and Relationship Education.

Astone. Nan. N . \& Mclanathan. S. Sara (1991). Family Structure, Parental Pratices and High School Completion. American Sociological Review. https://doi.org/10.2307/2096106
Ayodele S.O (2006). Educational Opportunities for Nigerian Learners: How do we Fare thus Far? A Paper Presented at the Workshop Organised by Network for Gender for Sensitive Educational Management in Africa and the British Consul in Nigeria.

Azuka-Obieke. Uchenna. (2013). Single-Parenting, Psychological Well-Being and Academic Performance of Adolescents in Lagos, Nigeria. Journal of Emerging Trends in Educational Research and Policy Studies (Jeteraps) :4(1): 112-117.

Baginski H.K (2007). Reasons why Women have Induced Abortion. East Africa Medical Journal. 90:10.

Bartley S.H (2010). Scholarships and Child's Education. University of Chicago Press.

Dogget. A.(2004). Juvenile Delinquency and Family Structure. Retrieved http://facstaff.elon.edu/ajoness/Anikas paper.

Dowd N. (1997). In Defence of Single Families. New York: New York University Press. ISBN: 978-0-8147-1916-9.

Ebizie E. Nkechi, Enajedu E. Ewomanoghene \& Nkechi. Egenti (2016). The Role of Guidance and COUNSELLING in Effective Teaching and Learning in Schools. International Journal of Multidisciplinary Studies: 1:36-48.

Fadeiye J.D (1985). A Text of Social Studies: Socialisation and Political Culture International Organisation for NCE and Undergraduates. Ibadan: Etori.

Fekadu. K. Ayichew. (2013). THE Paradox in Environmental Determinism and Possibilism: A LITERATURE Review. Journal of Geography and Regional Planning: 7:132-139. https://doi.org/10.5897/JGRP2013.0406

Holy Bible, King James Version.

Hunter. S \& John. W (2000). Children on the Brick: Updated Estimates and Recommendations for Intervention. Washington DC: USAID/the Synergy Project, Executive Summary.

Ibrahim U. (2015). Effects of Broken Home on Student Academic Performance in Esan West Local Government of EDO State.

Igbinosa V.O (2014). Influence of Broken Homes on Academic Performance and Personality Development of the Adolescents in Lagos State Metropolis. European Journal of Educational Development Psychology: 2 :10-23.

Lewin A.C (2005). The Effect of Economic Stability on Family Stability Among Welfare Recipients. Sloan Centre for Working Families, University of Chicago. https://doi.org/10.1177/0193841X04272558

Mirror. C.W (2003). Bleeding or Blessed Union. Lagos Life Press Ltd.

Mohase T.B (2006). The Influnce of Teenage Pregnancy and Parenting on the Performance of Soshanguve Secondary Schools Leraners. Unpublished M.Ed Thesis, Tshwane University of Technology.

Nyarko. Kingsley \& Vorgelegt. Von. (2007). Parental Involvement: A Sine Qua Non in Adolescents educational achievements. Unpublished doctoral dissertation. Ludwig-Maximilians University.

Nwachi (2000). Family and education. Onitsha pacific college Press Ltd.

Okorodudu G.N. (2010). Influence of Parenting Style on Adult Delinquency in Delta Central Senatorial District. EDO Journal of Counselling. https://doi.org/10.4314/ejc.v3i1.52682

Politt. Katha. (1994). Bothered and Bewildered. Reproductive Health Matters.4:71. https://doi.org/10.1016/0968-8080(94)90011-6

Roehlkepartain. C. Roehlkepartain \& Peter. C. Scales (2003). Boosting Student's Achievement. New Research on the Power of Development Asset. Search Institute Insights Evidence :1-10.

Sanna. K \& Jani. E (2016). The Effect of Early Parental Death on Children's Education. Turku Centre for Welfare Research. 
Steele F, Sigle-Rushton.W \& Kravdal.O (2009). Consequences of Family Disruption on Children's Education Outcomes in Norway. Demography: 46(3): 553-574. https://doi.org/10.1353/dem.0.0063

Undiyaundeye A.Florence, Agba A. Agba \& Mandeun. Terwase (2015). The Effect of Teenage Pregnancy on The Girl-Child in Nigeria Society. International Journal of Multidisciplinary Thought: 283-289.

Wright.N.Kelvin \& Wright.E.Karen (1994). Family Life, Delinquency and Crime: A Policymaker's Guide Research Summary. Washington DC: OJD:4-21.

Received on 30-06-2021

Accepted on 12-08-2021

Published on 23-08-2021

https://doi.org/10.6000/1929-4409.2021.10.154

(C) 2021 Ilori Oladapo Mayowa; Licensee Lifescience Global.

This is an open access article licensed under the terms of the Creative Commons Attribution Non-Commercial License (http://creativecommons.org/licenses/by-nc/3.0/) which permits unrestricted, non-commercial use, distribution and reproduction in any medium, provided the work is properly cited. 